BMJ Open

Diabetes

Research

\& Care

\section{Systematic review and meta-analysis of mouse models of diabetes-associated}

\section{ulcers}

\author{
Pacific Huynh (D),${ }^{1}$ James Phie, ${ }^{1}$ Smriti Murali Krishna, ${ }^{1}$ Jonathan Golledge (D) ${ }^{1,2}$
}

To cite: Huynh P, Phie J, Krishna SM, et al. Systematic review and meta-analysis of mouse models of diabetesassociated

ulcers. BMJ Open Diab Res Care 2020;8:e000982. doi:10.1136/

bmjdrc-2019-000982

- Additional material is published online only. To view please visit the journal online (http://dx.doi.org/10.1136/ bmjdrc-2019-000982).

Received 16 0ctober 2019 Revised 29 February 2020 Accepted 18 April 2020

\section{Check for updates}

(c) Author(s) (or their employer(s)) 2020. Re-use permitted under CC BY-NC. No commercial re-use. See rights and permissions. Published by BMJ.

${ }^{1}$ Queensland Research Centre for Peripheral Vascular Disease, James Cook University, Townsville, Queensland, Australia

${ }^{2}$ Department of Vascular and Endovascular Surgery, Townsville University Hospital, Townsville, Queensland, Australia

Correspondence to Professor Jonathan Golledge; jonathan.golledge@jcu.edu.au

\section{ABSTRACT}

Mouse models are frequently used to study diabetesassociated ulcers, however, whether these models accurately simulate impaired wound healing has not been thoroughly investigated. This systematic review aimed to determine whether wound healing is impaired in mouse models of diabetes and assess the quality of the past research. A systematic literature search was performed of publicly available databases to identify original articles examining wound healing in mouse models of diabetes. A meta-analysis was performed to examine the effect of diabetes on wound healing rate using random effect models. A meta-regression was performed to examine the effect of diabetes duration on wound healing impairment. The quality of the included studies was also assessed using two newly developed tools. 77 studies using eight different models of diabetes within 678 non-diabetic and 720 diabetic mice were included. Meta-analysis showed that wound healing was impaired in all eight models. Meta-regression suggested that longer duration of diabetes prior to wound induction was correlated with greater degree of wound healing impairment. Pairwise comparisons suggested that non-obese diabetic mice exhibited more severe wound healing impairment compared with $d b / d b$ mice, streptozotocin-induced diabetic mice or high-fat fed mice at an intermediate stage of wound healing $(p<0.01)$. Quality assessment suggested that the prior research frequently lacked incorporation of key clinically relevant characteristics. This systematic review suggested that impaired wound healing can be simulated in many different mouse models of diabetes but these require further refinement to become more clinically relevant.

\section{INTRODUCTION}

Diabetes-related foot disease (DFD) is a leading cause of impaired health-related quality of life, amputation, hospitalization and healthcare costs. ${ }^{1-6}$ The most common presentation of DFD is a foot ulcer which is estimated to develop in 10-20 million people worldwide annually. ${ }^{1}$ The lifetime incidence of foot ulceration in people with diabetes has been estimated as up to $30 \% .{ }^{14}$ The mortality of patients with diabetes-related foot ulcers has been estimated to be $50 \%$ over 5 years and more than double that of people with diabetes but no foot ulcer. ${ }^{178}$ The development of improved understanding of diabetes-related ulcer pathogenesis and the discovery of novel treatments are therefore global priorities.

Animal models of human disease are commonly used to identify new treatments. There are many methods of inducing diabetes that have been used to study atherosclerosis, nephropathy and neuropathy in mice. $^{9-11}$ There has, however, been limited focus on modeling DFD in mice. There is no current consensus on the most appropriate mouse model of diabetes-associated ulceration. A key requirement of a model of diabetes-associated ulceration is impaired wound healing. This has been attributed to several pathological processes stimulated by chronic hyperglycemia, including atherosclerosis and microvascular disease that lead to leg ischemia and peripheral neuropathy. ${ }^{12} 13$ It is not currently clear which of the different methods of inducing diabetes in mice are associated with wound healing impairment. In order to inform the appropriate choice of animal model, this review aimed to systematically examine the healing rates of wounds in mouse models of diabetes. The review also examined the quality and clinical relevance of this past research.

\section{METHODS}

\section{Search strategy, inclusion and exclusion criteria}

This review was performed according to the 2015 Preferred Reporting Items for Systematic Review and Meta-Analysis Protocols statement (online supplementary table 1$).{ }^{14}$ The protocol was registered in the PROSPERO database (Registration Number: CRD42018116224). Searches of the literature were conducted between 16 August 2018 and 24 January 2019 by one author (PH) on three separate occasions. The databases Medline, PubMed, Scopus, ScienceDirect and Web of Science were searched to identify preclinical studies examining the effects of diabetes on wound healing in mice. The 
full search strategy consisted of the terms ('diabetic wound' OR 'diabetic foot ulcer') AND (mouse OR mice OR murine) AND (nondiabetic OR non-diabetic OR normoglycemi* OR normoglycaemi*) using both Medical Subject Headings and keyword searches. The resultant articles were filtered in two stages, automatically using the database filters and manually by one author $(\mathrm{PH})$ to only include original journal articles written in English. For inclusion, studies had to examine wound healing in mouse models of diabetes compared with age-matched controls and report wound area as a ratio or percentage of the initial wound area monitored over time for both groups.

\section{Data extraction and quality assessment of included studies}

Full-text publications of included studies were independently assessed by two investigators ( $\mathrm{PH}$ and JP). Data extracted included sex, age and strain of mice, model of diabetes, diagnostic criteria for diabetes, whether diabetes was confirmed prior to wound generation, the size and location of the initial wound, method and period of monitoring, and wound closure percentage defined as detailed below. ImageJ V.1.48 (National Institutes of Health, USA) was used to extrapolate data from figures if required. Extracted data were discussed in a consensus meeting.

The quality of the included studies was assessed using two tools specifically developed for this systematic review (online supplementary tables 2 and 3). One tool assessed the study design and reporting quality of the studies and was based on a prior tool, ${ }^{15}$ and the Animal Research: Reporting of In Vivo Experiments guidelines (online supplementary table 2). The second tool assessed the design of the mouse model experiment in relation to recognized characteristic features of human diabetes-associated ulcers (online supplementary table 3 ). Each checklist item was weighted equally and graded $0,0.5$ or 1 for no, unclear or yes, respectively. Each study was scored as a percentage of the total possible score for each tool.

\section{Data analysis}

The primary outcome of this systematic review and meta-analysis was percentage $(\%)$ wound closure which was calculated from extracted data using the following formula:

$$
\% \text { Wound Closure }=\left(1-\frac{\text { Wound Area }}{\text { Initial Wound Area }}\right) \times 100 \%
$$

To gauge the effect of diabetes on wound closure over time, extracted data were sorted for analysis to early $(2-5$ days), intermediate (6-10 days) and late stages (11-20 days) of wound healing. In the event that a single article contained multiple independent animal studies, wound closure data were extracted from each of these studies and treated as independent data. If an article appeared to have multiple animal studies using the same mice in their experimental groups, sample sizes were evenly divided among them for meta-analysis to minimize duplication of data. For example, if primary outcome data were available for two different sets of diabetic mice but the authors used the same mice as controls for both, the sample size of the control group was evenly divided between the two diabetic groups for analysis. Corresponding authors of studies were contacted for key missing data. When necessary, SEMs were converted to SDs using GraphPad Prism V.7 (San Diego, California, USA). Meta-analyses were performed to assess the effect of diabetes on wound closure using Review Manager V.5.3.5 (Copenhagen: The Nordic Cochrane Centre, The Cochrane Collaboration, 2014), while meta-regression analyses were performed using Open Meta-Analyst. ${ }^{16}$ Since heterogeneity between studies was expected, random effects models were used. Data were reported as standardized mean difference (SMD) with $95 \%$ CIs. Subgroup analyses were performed to examine whether the extent of wound healing impairment was different between the models of diabetes included. These pairwise comparisons were corrected for multiple testing using Bonferroni's correction. Leaveone-out sensitivity analyses were also performed. The $\mathrm{I}^{2}$ index was used to assess the degree of heterogeneity between studies, with $\mathrm{I}^{2}>50 \%$ accepted to denote statistical heterogeneity. Funnel plots of the effect size versus the SEM of the log-transformed effect were constructed to assess potential publication bias. A $p$ value $<0.05$ was considered to be statistically significant.

\section{RESULTS}

\section{Study selection}

After a systematic search, a total of 77 studies were included in this systematic review and meta-analysis (online supplementary figure 1 ). ${ }^{17-93}$

\section{Characteristics of the included studies}

The characteristics of the 77 included studies are shown in online supplementary table 4 . There were a total of eight different mouse models of diabetes used (with three studies using multiple models). ${ }^{62} 6889$ These included streptozotocin (STZ) injection $(n=41 ; 20$ single dose; 21 multiple doses), leptin receptor defective $\mathrm{db} /$ db mice $(n=27)$, alloxan injection $(n=4 ; 3$ single dose; 1 multiple doses), high-fat fed mice $(\mathrm{n}=4)$, leptin-deficient $\mathrm{ob} / \mathrm{ob}$ mice $(\mathrm{n}=2)$ and non-obese diabetic (NOD) mice $(n=2)$. The majority of studies reported including male mice only (49/77). Eleven investigations included female mice only, two included mice of both sexes and the remaining studies did not report the sex of the mice included (15/77).

Only three studies examined wounds created in the hindlimb. ${ }^{37} 5161$ The other studies investigated wounds created on the torso of mice (74 in total; 71 on the back, 3 on the flank). The initial wound size differed greatly between studies (online supplementary table 4). Ten studies used splints to prevent the closure of wounds via contraction and promote wound healing through re-epithelialization since this has been suggested to be more typical of humans. ${ }^{9495}$ 
Quality of design and reporting of the included studies

The mean study design quality assessment score was $55.1 \%$ (range $19.2 \%-80.8 \%$ ) (online supplementary table 5). Most studies $(\mathrm{n}=73)$ provided an ethics statement. ${ }^{23}$ Only nine studies reported that examination of wound closure was performed by an assessor blinded to group allocation. Only two studies indicated that investigators were blinded to the experimental groups of mice. ${ }^{1772}$ Only three studies reported that power calculations were performed to determine appropriate sample sizes, ${ }^{32} 3747$ while an additional two justified their sample sizes based on previous experiments. ${ }^{63} 72$

Forty-one studies did not report full information about the strain of mice used. Twelve studies did not indicate the start date of their studies, ${ }^{20} 40-44485455578084$ with an additional 27 only reporting the age of mice as ranges. ${ }^{17-19} 212324262829363949-53606273787981$ 87-90 93 Eighteen studies which investigated STZ-induced diabetes did not indicate whether non-diabetic mice were injected with vehicle. $252730385154555860-6268717374787983$ In studies which used genetic models of diabetes, 14 used homozygote mice of the background strain or non-diabetic littermates, as controls mice, ${ }^{19-21} 2324294546505270818289$ while two studies did not indicate the use of littermate controls. ${ }^{4056}$ Two studies described the wound closure measurements in the methods but represented their data in another way. ${ }^{70} 85$

\section{Relevance of the reported mouse models to human diabetes- associated ulceration}

The mean clinical relevance quality assessment score was $44.9 \%$ (range $26.9 \%-65.4 \%$ ) (online supplementary table 6$)$. Most studies $(n=46)$ reported a clear diagnostic criterion for diabetes. This was mainly based on blood glucose concentrations. One study reported the confirmation of diabetes by the presence of glycosuria. ${ }^{20}$ Despite the Diabetic Complications Consortium recommendations for the appropriate confirmation of diabetes in animal models, only 15 of the 46 studies reported blood glucose measurements were performed in fasted mice $182533353865-697276778191$ and only three reported monitoring additional diabetes-associated metabolic parameters, with glycosuria being the common parameter measured. ${ }^{25} 5861$ Furthermore, only 16 studies extensively reported blood glucose levels of included mice. ${ }^{33} 35384249596063-65697477818791$ Only nine studies reported the time required for complete wound healing. ${ }^{183840526263808891}$ Four studies reported measures of wound blood supply, ${ }^{499} 7187$ with an additional study only reporting perfusion in a subset of mice. ${ }^{29}$ No investigation reported signs of neuropathy.

\section{The effect of diabetes on wound closure}

Meta-analyses included data extracted to assess the effect of diabetes on wound closure at early $(\mathrm{n}=1346)$, intermediate $(n=1398)$ and late $(n=870)$ stages of wound healing. Diabetes led to impairment of wound closure at all stages (SMD 1.25 (95\% CI 1.01 to $1.48, \mathrm{p}<0.001$ ), 2.28 (95\%
CI 1.94 to $2.62, \mathrm{p}<0.001)$ and $3.12(95 \%$ CI 2.66 to 3.59 , $\mathrm{p}<0.001)$ at early, intermediate and late stages, respectively (figures 1-3 and online supplementary tables 7-9)). There was substantial statistical heterogeneity between studies $\left(\mathrm{I}^{2}=70 \%-80 \%\right.$, figures $1-3$ and online supplementary tables 7-9).

Subgroup analyses suggested that wound closure was significantly impaired when compared with non-diabetic mice at all stages of wound healing in all models of diabetes (figures 1-3 and online supplementary tables 7-9) except in the high-fat fed mice and ob/ob mice at the early stage of wound healing (SMD -0.17 (95\% CI -0.89 to 1.23 ), and SMD 3.55 (95\% CI -0.07 to 7.18 ), respectively) (figure 1 and online supplementary table 7). Pairwise comparisons suggested significant differences in the degree of wound healing impairment in the different diabetes models (online supplementary table $10)$. $d b / d b$ mice had greater wound healing impairment than found in the multiple-dose STZ-induced and high-fat fed models at intermediate and late stages of wound healing (online supplementary table 10). The single-dose STZ-induced diabetes model had more severe wound healing impairment than the multiple-dose STZinduced diabetes model at late stages of wound healing (online supplementary table 10).

Meta-regression suggested that a longer duration of diabetes prior to wound generation was associated with greater impairment of wound healing (online supplementary figure $2 \mathrm{c}, \mathrm{p}=0.021$ at late stages after removal of statistical outliers). Leave-one-out sensitivity analyses suggested that all studies contributed towards the main findings in the meta-analysis (online supplementary figure 3). Funnel plots suggested potential publication bias (online supplementary figure 4 ).

\section{DISCUSSION}

This systematic review suggests that mouse models of diabetes consistently have impaired wound healing. The wound healing impairment was clearer as the time after wound induction increased. The severity of wound healing impairment varied between the different mouse models. The meta-regression suggested a tendency towards greater wound healing impairment with longer duration of hyperglycemia. There was substantial statistical heterogeneity and limited reporting of important information in the included studies. Furthermore, very few studies modeled some of the common characteristics of human diabetes-associated ulcers, such as location in the periphery of the limb and concurrent ischemia and neuropathy (online supplementary table 11). These findings highlight the need for more clinically relevant models of diabetes-associated ulceration.

Eight different methods of modeling diabetes were used in the studies included in this systematic review (summarized in table 1, sorted from most to least severe wound healing impairment). Meta-analysis of data reported early after wound induction suggested that the 


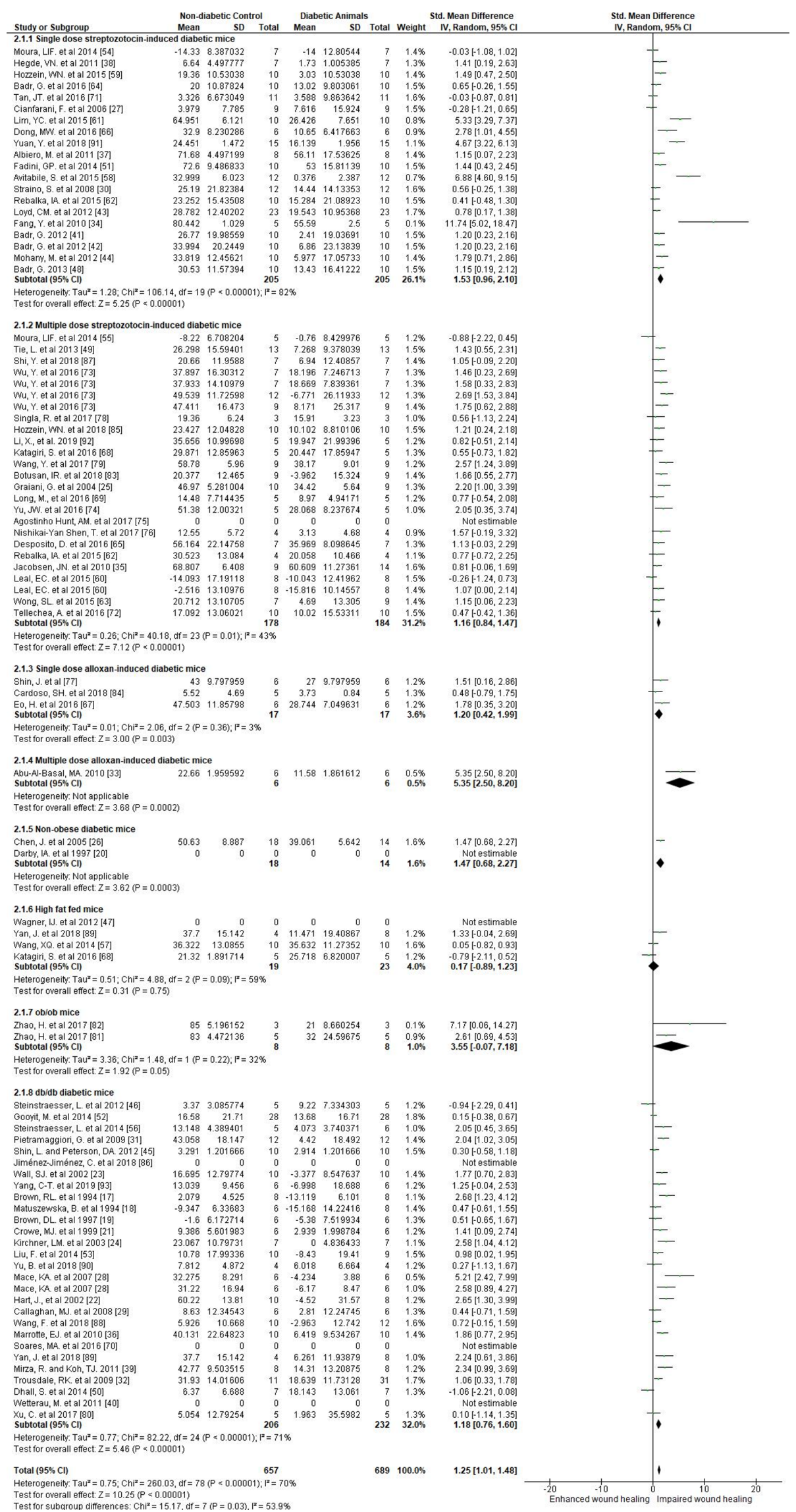

Figure 1 Forest plots showing the effect of diabetes on the early stages of wound closure in different mouse models of diabetes. Forest plots were generated from Review Manager V.5.3 to represent early (2-5 days) stages of wound closure. Comparisons were made using standard mean differences and random effects models. 
Std. Mean Difference Std. Mean Difference

\begin{tabular}{|c|c|c|c|c|c|}
\hline & \multicolumn{2}{|l|}{ Non-diz } & \multicolumn{3}{|c|}{ imm } \\
\hline & $\begin{array}{c}\text { Mean } \quad \text { SD } \\
\text { ced diabetic mice }\end{array}$ & & & & \\
\hline & $39 \quad 11.4561$ & & 38.67 & & \\
\hline & $\begin{array}{ll}20.14 & 5.221213 \\
55.21 & 15.30542\end{array}$ & 10 & $\begin{array}{l}8.81 \\
22.08\end{array}$ & $\begin{array}{l}1.8 .822026 \\
13.40806\end{array}$ & \\
\hline 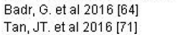 & $\begin{array}{r}60.31 \quad 10.87824 \\
17779 \\
11445554\end{array}$ & $\begin{array}{l}10 \\
11\end{array}$ & 26.2 & 8.348413 & \\
\hline 71 & $\begin{array}{l}17179911: \\
4827 \\
48\end{array}$ & & $\begin{array}{l}\begin{array}{l}14.802 \\
34.934\end{array} \\
\end{array}$ & & \\
\hline & $\begin{array}{r}49.555 \\
49.58512 \\
6.816\end{array}$ & & $\begin{array}{l}3.321 \\
5.321\end{array}$ & 整.709 & \\
\hline $18[91]$ & $\begin{array}{rr}66.36 & 5.4868577 \\
60.147 & 1.834\end{array}$ & $\begin{array}{r}6 \\
15\end{array}$ & $\begin{array}{r}25.98 \\
25.94\end{array}$ & $\begin{array}{l}9.626495 \\
1938\end{array}$ & \\
\hline 371 & $100 \quad 4.016367$ & 8 & 83.89 & 5.996266 & \\
\hline $12015[58]$ & $\begin{array}{rr}94.7 & 12.64911 \\
55.709 & 6.77\end{array}$ & $\begin{array}{l}10 \\
12\end{array}$ & $\begin{array}{r}80 \\
15.934\end{array}$ & $\begin{array}{l}4.46833 \\
3.388 \\
\end{array}$ & \\
\hline 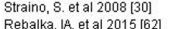 & 83.8911 .11977 & 12 & 73.89 & & \\
\hline [6] & 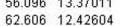 & & $\begin{array}{l}45.691 \\
5.971\end{array}$ & $\begin{array}{l}2.3 .657 \\
1.164\end{array}$ & \\
\hline & 1 & 5 & $\begin{array}{l}64.479 \\
64.479\end{array}$ & 2.208 & \\
\hline 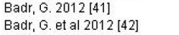 & & $\begin{array}{l}10 \\
10\end{array}$ & $\begin{array}{l}14.44 \\
015.51\end{array}$ & & \\
\hline & $\begin{array}{l}17.05733 \\
17.0533 \\
\end{array}$ & 10 & 15.889 & $\begin{array}{l}2.6129393 \\
14.29033\end{array}$ & \\
\hline & & & & & \\
\hline
\end{tabular}
Heterogeneit: Tau $^{2}=2.27 ; \mathrm{Ch}^{2}=148.95$, df $=19(\mathrm{P}<0.00001) ; \mathrm{P}=87 \%$ Test for overall effect: $Z=5.49(P<0.0000)$

\begin{tabular}{|c|c|c|}
\hline \multicolumn{3}{|r|}{ betic mice } \\
\hline Moura, LFF. et al 2014 [55] & 32.52 & \\
\hline Tie, L. et al 2013 [49] & 67.993 & 6.861364 \\
\hline Shi, Y. et al 2018 [87] & 52.43 & 11.48256 \\
\hline$W u, Y$, et al 2016 [73] & 82.079 & 7.246713 \\
\hline Mu, Y. et al 2016 [73] & 82.371 & 7037698 \\
\hline Wu, Y. et al 2016 [73] & 67.73 & 13.2174 \\
\hline Wu, Y. et al 2016 [73] & 81.86 & 6.948988 \\
\hline Singla, R. et al $2017[78]$ & 51.4 & 13.98 \\
\hline Hozzein, WN. et al 2018 [85] & 46.124 & 14.84373 \\
\hline Li, X. et al. $2019[92]$ & 53.142 & 7.949222 \\
\hline Katagiri, S. et al 2016 [68] & 81.295 & $\begin{array}{r}.340223 \\
6.039\end{array}$ \\
\hline Wang, Y. et al 2017 [79] & 92.36 & 3.52 \\
\hline Botusan, IR. et al 2018 [83] & 63.396 & 6.225 \\
\hline Graiani, $G$, et al 2004 [25] & 72.88 & 3.734234 \\
\hline Long, M, et al 2016 [69] & 54.35 & 7.401385 \\
\hline Yu, JW. et al 2016 [74] & 74.847 & 7.553438 \\
\hline Agostinho Hunt, AM. et al 2017 [75] & 90.306 & 3.827 \\
\hline Nishikai-Yan Shen, T. et al 2017 [76] & 63.12 & 9.36 \\
\hline Desposito, D. et al 2016 [65] & 76.86 & 9.262775 \\
\hline Rebalka, $\mid \mathcal{A}$, et al 2015 [62] & 57.703 & 10.76 \\
\hline Jacobsen, JN. et al 2010 [35] & 95.853 & 5.841 \\
\hline eal, EC. et al 2015 [60] & 32.752 & 12.2584 \\
\hline I. EC. et al $2015[60]$ & 23.207 & 15.28199 \\
\hline g. SL. et al 2015 [63] & 50.325 & 13.45365 \\
\hline al 2016 [72] & 64.44 & 18.0155 \\
\hline
\end{tabular}

Heterogeneity: Tau $^{2}=0.67 ; \mathrm{Chi}^{2}=62.28, \mathrm{df}=24(\mathrm{P} \approx 0.0001) ;{ }^{2}=61$

$\begin{array}{rrr}5 & 30.94 & 9.279682 \\ 3 & 39.966 & 19.33657\end{array}$

$\begin{array}{rrrr}7 & 17.89 & 13.33459\end{array}$

$\begin{array}{lll}7 & 65.118 & 8.686002\end{array}$

$\begin{array}{rrrr}7 & 65.33 & 9.8078 \\ 5 & 35.623 & 18.93055\end{array}$

$\begin{array}{rrr}12 & 32.929 & 22.92196 \\ 3 & 41.51 & 7.32\end{array}$

$\begin{array}{rrrr}10 & 41.51 & 7.32 \\ 10 & 19.18 & 9.259149\end{array}$

19.931
5 11.91824

$\begin{array}{rrr}9 & 40.179 & 15.669 \\ 9 & 78.17 & 5.19 \\ 9 & 47169 & 18.687\end{array}$

$\begin{array}{rr}47.169 & 18.687 \\ 64.29 & 4.648548\end{array}$

64.29
44.648548
54.653583

$\begin{array}{rrrr}21.56 & 13 & 10 & 0.8 \% \\ 4 & 0.8 \%\end{array}$

$\begin{array}{rrrr}67.346 & 5.074551 & 7 & 1.4 \% \\ 51.599 & 9.03 & 4 & 1.3 \%\end{array}$

$93.226 \quad 4.224331 \quad 14 \quad 1.5 \%$

$\begin{array}{rrrr}9.588 & 18.17547 & 8 & 1.4 \% \\ 21.181 & 13.85081 & 8 & 1.5 \%\end{array}$

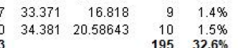

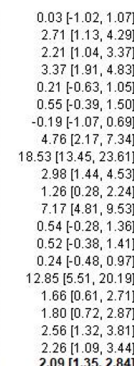

$2.009135,284$

(est for overall effect. $Z=7.86(P<0.0000)$

2.2.3 Single dose alloxan-induced diabetic mice

$\begin{array}{lrrrrrrrr}\text { Shin, J. et al [77] } & 79 & 4.898979 & 6 & 52 & 9.797959 & 6 & 1.1 \% & 3.22[1.28,5.15] \\ \text { Cardoso, SH. et a | 2018 [84] } & 27.86 & 5.11 & 5 & 13.52 & 2.09 & 5 & 1.0 \% & 3.32[1.08,5.56]\end{array}$

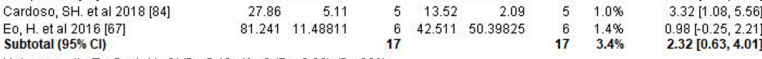
Heterogeneity: Tau $^{2}=1.41 ; \mathrm{Chi}^{2}=5.48$, df $=2$
Test for overall effect: $Z=2.69(P=0.007)$

2.2.4 Multiple dose alloxan-induced diabetic mice

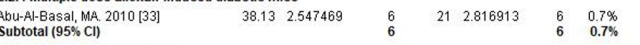

Heterogeneity: Not applicable
Test for overall effect: $Z=3.74(P=0.0002)$

2.2 .5 Non-obese diabetic mice

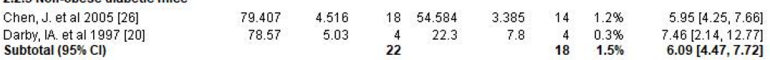

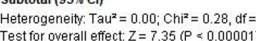

2.2.6 High fat fed mice

Wagner, IJ eta

Yan, J. et al 2018 [89]

Katagiri, 5 . et al al $2016[6]$
Subtotal $(95 \% \%$ CI)

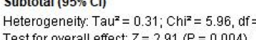

2.2.7 oblob mice

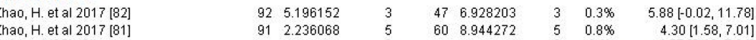

$\begin{array}{llllll}8 & 60 & 8.944272 & 5 & 0.8 \% & 4.30[1.58,7.01]\end{array}$

Heterogeneity: Tau $=0.00 ; \mathrm{Chi}^{2}=0.23$,
Test for overall effect. $Z=3.63(\mathrm{P}=0.0003)$

2.8 db/db diabetic mice

Steinstraesser, L. et al $2012[46$

Goovit, M. et al 2014 [52]

Pietramaggiori, G. et al 2009 [31]

Shin, L. and Peterson, DA. 2012 [45]

Whall, 8J. et al 2002 [23]

Brown, RL et al $1994[17]]$
Matuszewska, B. et al $1994[18]$

Brown, DL. et al 1997 (19)

Kirchner, LM. et al 2003 [24]

iu, F. et al 2014 [53]

Yu, B. et al 2018 [90]

Mace, KA, et al 2007 [28]
Mace, KA, et a a 2007 [28]

Callaghan, MJ. et al 2008 [29]

Wang. F. et al $2018[88]$

Marrotte, EJ. et al 2010 [36]

Soares, MA. et a a 2016 [D

Mirza, R and Koh, TJ. 2011 [39]

Trousdale, RK. et al 2009 [32]

Dhall, S. et al 2014 [50]

Wetterau, M. et al 2011
Xu, C. et al 2017 20180$]$

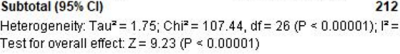

Total $(95 \% \mathrm{Cl})$

678

Heterogenty. $\mathrm{Tau}^{2}=1.74 ; \mathrm{Chi}^{2}=4$

25.469 .592732

$\begin{array}{rr}64.21 & 15.13 \\ 40.699 & 6.880381\end{array}$

$\begin{array}{rr}70.272 & 8.742 \\ 14.557 & 5.21775\end{array}$

$\begin{array}{lll}55.081 & 10.96392 \\ 56.998 & 13.34165\end{array}$

$\begin{array}{rrr}61.2 & 12.1169 \\ 38.927 & 14.4299\end{array}$

$\begin{array}{ll}83.877 & 21.16359 \\ 20.099 & 8.759375\end{array}$

$\begin{array}{rr}65.825 & 10.79202 \\ 52.75 & 22.32568\end{array}$

$\begin{array}{rr}42.79 & 52.3258 \\ 67.195 & 2.827 \\ 8.92\end{array}$

$\begin{array}{rr}0 & 0 \\ 85.96 & 9.38\end{array}$

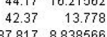

$\begin{array}{rr}87.817 & 8.838566 \\ 67.35 & 3.25\end{array}$

\begin{tabular}{rr}
67.35 & 3.25 \\
69.433 & 24.164 \\
\hline
\end{tabular}

\begin{tabular}{rr}
88.18 & 4.129504 \\
\hline
\end{tabular}

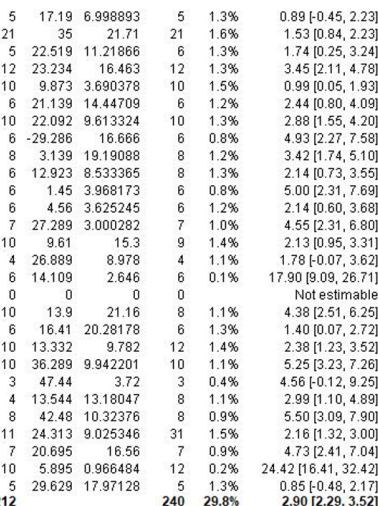

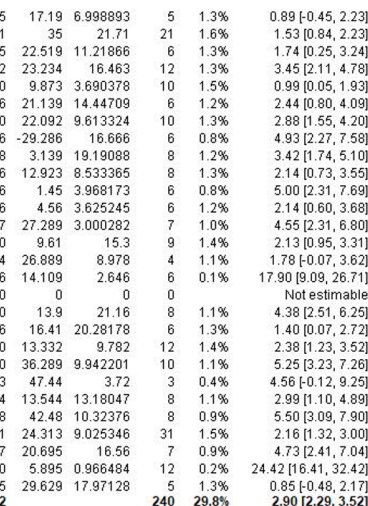

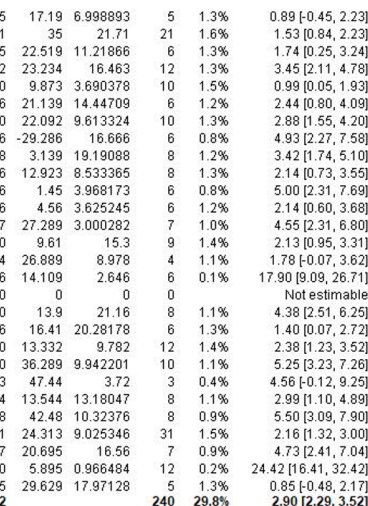

$.89[-0.45,2.23]$
$1.53[0.84,2.23]$

$[0.05,1.93]$

$[1.55,4.20]$

$.42[1.74,5.10]$
$.14[0.73,3.55]$

$4[0.60,3.68]$

$13[0.95,3.31]$

$[9.09,26.71]$

$2.51,6.25]$
$[0.07,2.72]$

$8[1.23,3.52]$

$[0.12,9.25]$

$0.10,4.89]$
$[3.09,7.90]$
$6[1.32,3.00]$

$.73[2.41,7.04]$
$[16.41,32.42]$

$0.85[-0.48,2.17]$
$2.90[2.29,3.52]$

$F^{2}=80 \%$

$720 \quad 100.0 \% \quad 2.28[1.94,2.62]$

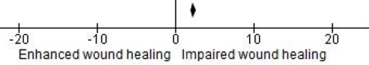

Figure 2 Forest plots showing the effect of diabetes on the intermediate stages of wound closure in different mouse models of diabetes. Forest plots were generated from Review Manager V.5.3 to represent intermediate (6-10 days) stages of wound closure. Comparisons were made using standard mean differences and random effects models. 


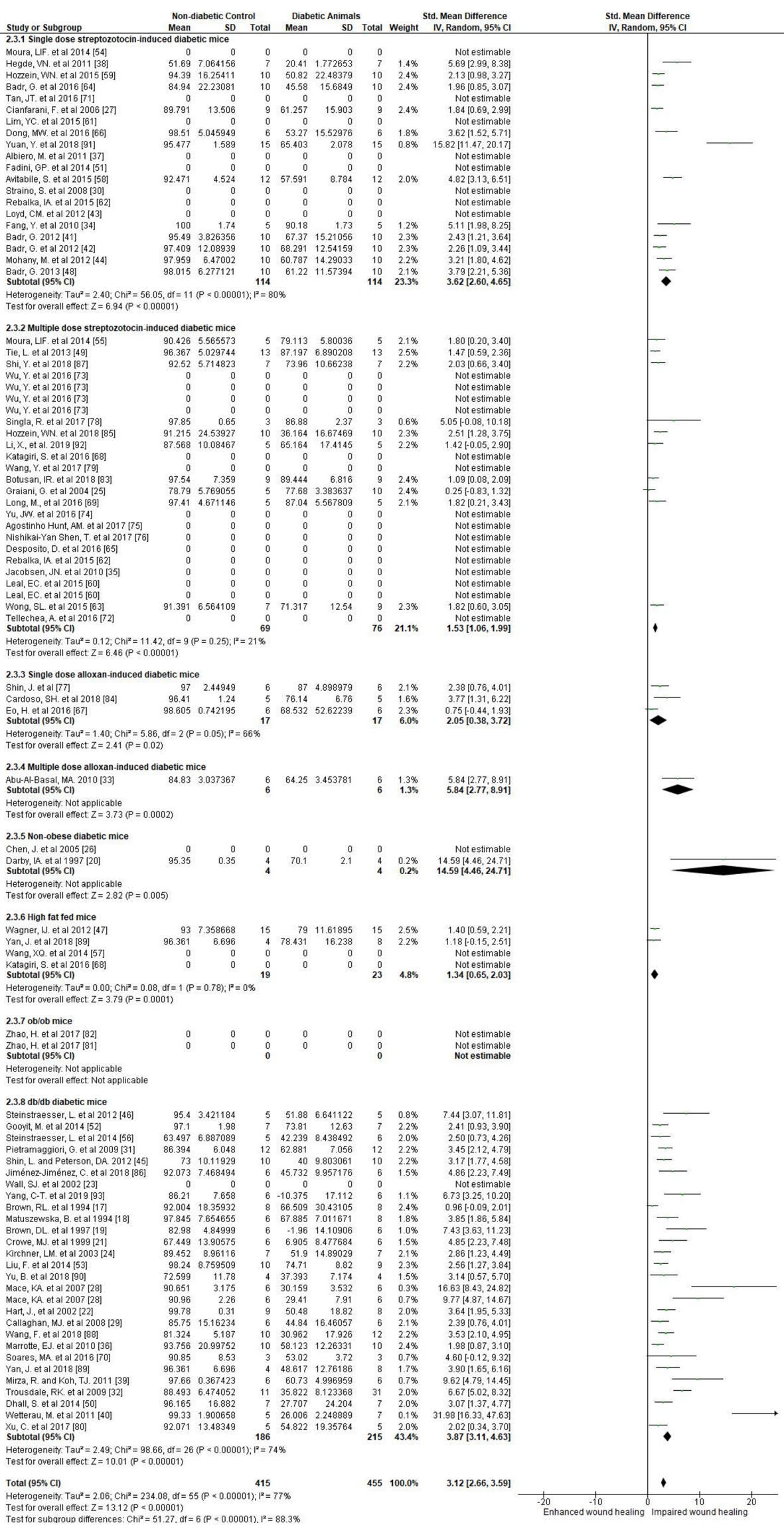

Figure 3 Forest plots showing the effect of diabetes on the late stages of wound closure in different mouse models of diabetes. Forest plots were generated from Review Manager V.5.3 to represent late (11-20 days) stages of wound closure. Comparisons were made using standard mean differences and random effects models. 


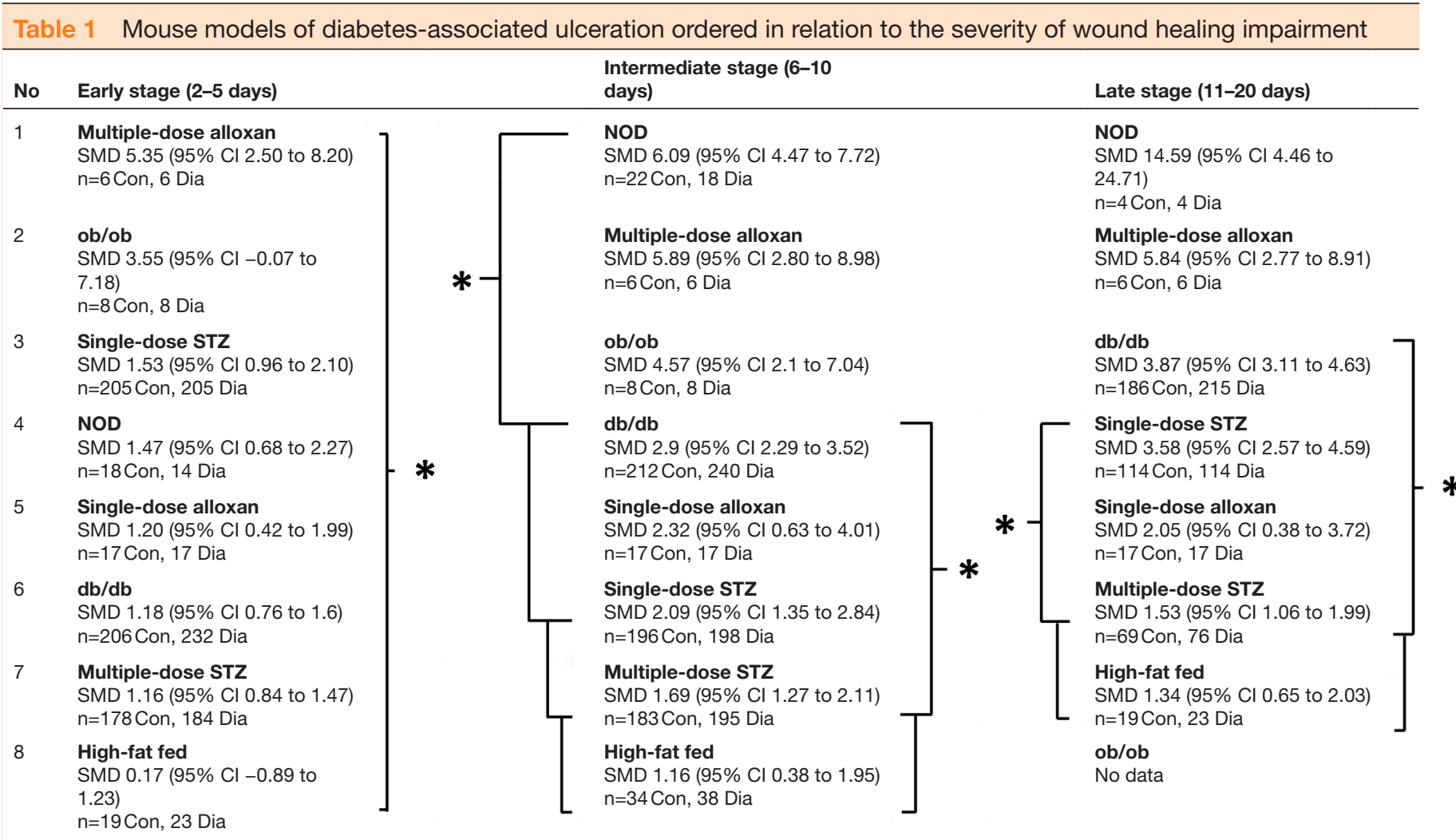

${ }^{*} \mathrm{P}<0.01$, significant differences as determined by pairwise comparison using Bonferroni's correction (online supplementary table 10).

Con, non-diabetic control; Dia, diabetic; NOD, non-obese diabetic; SMD, standardized mean difference; STZ, streptozotocin.

multiple-dose alloxan-induced diabetes model had the most severe wound healing impairment. Meta-analyses of data reported at intermediate and late stages after wound induction suggested that NOD mice had the most severe impairment of wound healing. These findings, however, should be interpreted cautiously given the small and uneven number of studies which reported the use of these models. Indeed, only a total of three studies reported the use of the multiple-dose alloxan-induced diabetes and NOD models. The infrequent use of these models is likely due to a number of factors. First, both models simulate type 1 rather than type 2 diabetes, which is the less common form of diabetes in people. ${ }^{96}$ Second, these models have disadvantages compared with the more commonly used mouse models of diabetes. For example, alloxan is generally considered less favorable as a diabetogenic agent to STZ due to greater organ toxicity and lower effectiveness, ${ }^{97}$ while NOD mice have variable onset of diabetes. ${ }^{98}$ Nonetheless, these models do appear to simulate diabetes-associated wound healing impairment. High-fat feeding is an approach used to simulate type 2 diabetes. This review suggested that this model had the least severe wound healing impairment of all the models examined, possibly due to its milder metabolic derangement. Meta-analyses of data obtained late after wound induction also suggested that impairment of wound healing was more severe in the singledose STZ-induced diabetes model compared with the multiple-dose STZ-induced diabetes model. It should be noted though that there were substantial methodological differences between the included studies. These comparisons between models should therefore be interpreted very cautiously.

It was surprising to find limited reporting of relevant metabolic parameters and data to confirm the diagnosis of diabetes within the included studies. Susceptibility towards diabetes-associated complications in mice is dependent on a number of different factors, such as age, strain and sex. ${ }^{99-102}$ Furthermore, studies focusing on other diabetic complications, such as atherosclerosis and neuropathy, typically require an extended duration of diabetes, as well as genetic manipulation, to simulate these complications. ${ }^{9-11} 103104$ In the meta-regression, there was a trend towards greater wound healing impairment with longer duration of hyperglycemia before wound induction (online supplementary figure 2). Many of the studies with a relatively long duration of diabetes ( $>6$ weeks) used genetic models which may have influenced the findings of the meta-regression. Nonetheless, investigators should take into consideration the severity and duration of diabetes required to simulate the clinical presentation.

While limbs are the main site of diabetes-associated ulcers in patients, all but three studies included in this systematic review examined wounds generated on the torso of mice. The greater area on the torso allows multiple wounds to be studied but it is unlikely such ulcers simulate the clinical situation. Peripheral artery disease 
Table 2 Proposed reporting standards for mouse models of diabetes-associated ulceration

Elevated and sustained glycemia

Diabetes should be validated by more than one method, as per recommendations by DiaComp, and, ideally, performed multiple times.

Suggested criteria:

- Fasting blood glucose $>8.33 \mathrm{mmol} / \mathrm{L}$ (highly recommended) or otherwise random blood glucose $>15 \mathrm{mmol} / \mathrm{L}$.

- Validation via intraperitoneal glucose tolerance test, or euglycemic clamp on awake and conscious animals.

Presence of ischemia

Presence of neuropathy

Location of wound on periphery

Possible infection could be considered
- May be examined using laser Doppler or similar techniques.

- May be artificially induced via ligation/obstruction/excision of local major artery.

- May be examined by electrophysiology, behavioral tests and/or histology.

Ideally on the foot/paw.

May be artificially induced.

DiaComp, Diabetic Complications Consortium.

and neuropathy are key causes of ulcers in people. Only four of the included studies examined blood flow within the mice. ${ }^{49697187}$ None of the included studies artificially induced artery disease or neuropathy within the mice. Artificial generation of peripheral ischemia or neuropathy is likely required to simulate the clinical presentation since mice are very resistant to development of diabetes-associated microvascular complications. ${ }^{105}$ Use of genetically modified mice may also be used to simulate other clinically relevant risk factors, such as dyslipidemia which accelerates diabetes-associated atherosclerosis and neuropathy. ${ }^{106107}$ Table 2 presents suggested criteria for future diabetes-associated ulcer studies in rodents aimed to improve the clinical relevance of the research.

\section{Limitations and strengths}

To the best of our knowledge, this is the first systematic review and meta-analysis examining wound healing impairment in different mouse models of diabetes. The current study used a range of analysis methods and quality assessment methods in order to rigorously assess past research. The included studies had many quality weaknesses such as small sample sizes. There was also absence of key study design and reporting features, like blinding of outcome assessors and inclusion of sample size calculations. Many of the included studies did not report parameters relevant to diabetes or determined the severity of diabetes. Therefore, it was not possible to systematically assess the correlation between glucose control and wound healing impairment. There was also statistical and methodological heterogeneity between studies. Due to the heterogeneous and intermittent reporting of outcomes, it was not possible to systematically examine the molecular mechanisms involved in wound healing impairment. Nonetheless, the findings from this study provide important insight into the strengths and weaknesses of current mice models of diabetes-associated ulcers.

\section{CONCLUSION}

In conclusion, this systematic review suggests that, regardless of diabetes induction method, hyperglycemia impairs wound healing in mice. Incorporation of clinically relevant aspects, such as limb ischemia and prolonged diabetes duration, may improve the translation of findings from the mouse models.

Acknowledgements We thank Emeritus Professor Rhondda Jones for her statistical advice.

Contributors PH, JP, SMK and JG were responsible for the conceptualization of the review, with data curation and analysis performed by PH and JP. The writing of this manuscript was performed by PH and JG.

Funding This work was supported by James Cook University's Strategic Research Intent Fund. JG holds a National Health and Medical Research Council (NHMRC) Practitioner Fellowship (1117061) and Queensland Government Senior Clinical Research Fellowship (SCRF).

Competing interests None declared.

Patient consent for publication Not required.

Provenance and peer review Not commissioned; externally peer reviewed.

Data availability statement All data relevant to the study are included in the article or uploaded as supplementary information.

Open access This is an open access article distributed in accordance with the Creative Commons Attribution Non Commercial (CC BY-NC 4.0) license, which permits others to distribute, remix, adapt, build upon this work non-commercially, and license their derivative works on different terms, provided the original work is properly cited, appropriate credit is given, any changes made indicated, and the use is non-commercial. See: http://creativecommons.org/licenses/by-nc/4.0/.

ORCID IDs

Pacific Huynh http://orcid.org/0000-0001-6729-2296

Jonathan Golledge http://orcid.org/0000-0002-5779-8848

\section{REFERENCES}

1 Armstrong DG, Boulton AJM, Bus SA. Diabetic foot ulcers and their recurrence. N Engl J Med 2017;376:2367-75.

2 Boulton AJM, Vileikyte L, Ragnarson-Tennvall G, et al. The global burden of diabetic foot disease. Lancet 2005;366:1719-24.

3 Lazzarini PA, Hurn SE, Fernando ME, et al. Prevalence of foot disease and risk factors in general inpatient populations: a systematic review and meta-analysis. BMJ Open 2015;5:e008544.

4 Boulton AJM, Kirsner RS, Vileikyte L. Neuropathic diabetic foot ulcers. N Engl J Med Overseas Ed 2004;351:48-55.

5 Baker IDI Heart and Diabetes Institute. National evidence-based guideline on prevention, identification and management of foot complications in diabetes. Melbourne Australia, 2011.

6 Lazzarini PA, Pacella RE, Armstrong DG, et al. Diabetes-Related lower-extremity complications are a leading cause of the global burden of disability. Diabet Med 2018. doi:10.1111/dme.13680. [Epub ahead of print: 23 May 2018]. 
7 Walsh JW, Hoffstad OJ, Sullivan MO, et al. Association of diabetic foot ulcer and death in a population-based cohort from the United Kingdom. Diabet Med 2016;33:1493-8.

8 Iversen MM, Tell GS, Riise T, et al. History of foot ulcer increases mortality among individuals with diabetes: ten-year follow-up of the Nord-Trøndelag health study, Norway. Diabetes Care 2009;32:2193-9.

9 Kleinert M, Clemmensen C, Hofmann SM, et al. Animal models of obesity and diabetes mellitus. Nat Rev Endocrinol 2018;14:140-62.

10 Jolivalt CG, Frizzi KE, Guernsey L, et al. Peripheral neuropathy in mouse models of diabetes. Curr Protoc Mouse Biol 2016;6:223-55.

11 Azushima K, Gurley SB, Coffman TM. Modelling diabetic nephropathy in mice. Nat Rev Nephrol 2018;14:48-56.

12 Davis FM, Kimball A, Boniakowski A, et al. Dysfunctional wound healing in diabetic foot ulcers: new crossroads. Curr Diab Rep 2018;18:2.

13 Nativel M, Potier L, Alexandre L, et al. Lower extremity arterial disease in patients with diabetes: a contemporary narrative review. Cardiovasc Diabetol 2018:17:138.

14 Moher D, Shamseer L, Clarke M, et al. Preferred reporting items for systematic review and meta-analysis protocols (PRISMA-P) 2015 statement. Syst Rev 2015;4:1.

15 Phie J, Krishna SM, Moxon JV, et al. Flavonols reduce aortic atherosclerosis lesion area in apolipoprotein $\mathrm{E}$ deficient mice: a systematic review and meta-analysis. PLoS One 2017:12:e0181832.

16 Wallace BC, Dahabreh IJ, Trikalinos TA, et al. Closing the Gap between Methodologists and End-Users: $R$ as a Computational Back-End. J Stat Softw 2012;49:15.

17 Brown RL, Breeden MP, Greenhalgh DG. Pdgf and TGF-alpha act synergistically to improve wound healing in the genetically diabetic mouse. J Surg Res 1994;56:562-70.

18 Matuszewska B, Keogan M, Fisher DM, et al. Acidic fibroblast growth factor: evaluation of topical formulations in a diabetic mouse wound healing model. Pharm Res 1994;11:65-71.

19 Brown DL, Kao WW, Greenhalgh DG. Apoptosis down-regulates inflammation under the advancing epithelial wound edge: delayed patterns in diabetes and improvement with topical growth factors. Surgery 1997;121:372-80.

20 Darby IA, Bisucci T, Hewitson TD, et al. Apoptosis is increased in a model of diabetes-impaired wound healing in genetically diabetic mice. Int J Biochem Cell Biol 1997;29:191-200.

21 Crowe MJ, McNeill RB, Schlemm DJ, et al. Topical application of yeast extract accelerates the wound healing of diabetic mice. $J$ Burn Care Rehabil 1999;20:155-62.

22 Hart J, Silcock D, Gunnigle S, et al. The role of oxidised regenerated cellulose/collagen in wound repair: effects in vitro on fibroblast biology and in vivo in a model of compromised healing. Int J Biochem Cell Biol 2002;34:1557-70.

23 Wall SJ, Bevan D, Thomas DW, et al. Differential expression of matrix metalloproteinases during impaired wound healing of the diabetes mouse. J Invest Dermatol 2002;119:91-8.

24 Kirchner LM, Meerbaum SO, Gruber BS, et al. Effects of vascular endothelial growth factor on wound closure rates in the genetically diabetic mouse model. Wound Repair Regen 2003;11:127-31.

25 Graiani G, Emanueli C, Desortes E, et al. Nerve growth factor promotes reparative angiogenesis and inhibits endothelial apoptosis in cutaneous wounds of type 1 diabetic mice. Diabetologia 2004;47:1047-54.

26 Chen J, Kasper M, Heck T, et al. Tissue factor as a link between wounding and tissue repair. Diabetes 2005;54:2143-54.

27 Cianfarani F, Zambruno G, Brogelli L, et al. Placenta growth factor in diabetic wound healing: altered expression and therapeutic potential. Am J Pathol 2006;169:1167-82.

28 Mace KA, Yu DH, Paydar KZ, et al. Sustained expression of HIF1 alpha in the diabetic environment promotes angiogenesis and cutaneous wound repair. Wound Repair Regen 2007;15:636-45.

29 Callaghan MJ, Chang El, Seiser N, et al. Pulsed electromagnetic fields accelerate normal and diabetic wound healing by increasing endogenous FGF-2 release. Plast Reconstr Surg 2008;121:130-41.

30 Straino S, Di Carlo A, Mangoni A, et al. High-Mobility group box 1 protein in human and murine skin: involvement in wound healing. $J$ Invest Dermatol 2008;128:1545-53.

31 Pietramaggiori G, Scherer SS, Alperovich M, et al. Improved cutaneous healing in diabetic mice exposed to healthy peripheral circulation. J Invest Dermatol 2009;129:2265-74.

32 Trousdale RK, Jacobs Sharone', Simhaee DA, et al. Wound closure and metabolic parameter variability in a $\mathrm{db} / \mathrm{db}$ mouse model for diabetic ulcers. J Surg Res 2009;151:100-7.
33 Abu-Al-Basal MA. Healing potential of Rosmarinus officinalis $L$. on full-thickness excision cutaneous wounds in alloxan-induceddiabetic BALB/c mice. J Ethnopharmacol 2010;131:443-50.

34 Fang Y, Shen J, Yao M, et al. Granulocyte-Macrophage colonystimulating factor enhances wound healing in diabetes via upregulation of proinflammatory cytokines. $\mathrm{Br} \mathrm{J}$ Dermatol 2010;162:478-86

35 Jacobsen JN, Steffensen B, Häkkinen L, et al. Skin wound healing in diabetic $\beta 6$ integrin-deficient mice. APMIS 2010;118:753-64.

36 Marrotte EJ, Chen D-D, Hakim JS, et al. Manganese superoxide dismutase expression in endothelial progenitor cells accelerates wound healing in diabetic mice. J Clin Invest 2010;120:4207-19.

37 Albiero M, Menegazzo L, Boscaro E, et al. Defective recruitment, survival and proliferation of bone marrow-derived progenitor cells at sites of delayed diabetic wound healing in mice. Diabetologia 2011;54:945-53.

38 Hegde VN, Prabhu V, Rao SBS, et al. Effect of laser dose and treatment schedule on excision wound healing in diabetic mice. Photochem Photobiol 2011;87:1433-41.

39 Mirza R, Koh TJ. Dysregulation of monocyte/macrophage phenotype in wounds of diabetic mice. Cytokine 2011;56:256-64.

40 Wetterau M, George F, Weinstein A, et al. Topical prolyl hydroxylase domain-2 silencing improves diabetic murine wound closure. Wound Repair Regen 2011;19:481-6.

41 Badr G. Supplementation with undenatured whey protein during diabetes mellitus improves the healing and closure of diabetic wounds through the rescue of functional long-lived wound macrophages. Cell Physiol Biochem 2012;29:571-82.

42 Badr G, Badr BM, Mahmoud MH, et al. Treatment of diabetic mice with undenatured whey protein accelerates the wound healing process by enhancing the expression of MIP- $1 \alpha$, MIP$2, \mathrm{KC}, \mathrm{CX} 3 \mathrm{CL} 1$ and TGF- $\beta$ in wounded tissue. BMC Immunol 2012;13:32.

43 Loyd CM, Diaconu D, Fu W, et al. Transgenic overexpression of keratinocyte-specific VEGF and Ang1 in combination promotes wound healing under nondiabetic but not diabetic conditions. Int $J$ Clin Exp Pathol 2012;5:1-11

44 Mohany M, Badr BM, Mahmoud M, et al. Un-denatured whey protein expedites wound healing in diabetic mice model by enhancing the expression of $\beta$-defensin 2, 3 and vascular endothelial growth factor (VEGF) in the wounded tissue. Afr $J$ Microbiol Res 2012;6:2137-44.

45 Shin L, Peterson DA. Impaired therapeutic capacity of autologous stem cells in a model of type 2 diabetes. Stem Cells Transl Med 2012;1:125-35.

46 Steinstraesser L, Hirsch T, Schulte M, et al. Innate defense regulator peptide 1018 in wound healing and wound infection. PLoS One 2012;7:e39373.

47 Wagner IJ, Szpalski C, Allen RJ, et al. Obesity impairs wound closure through a vasculogenic mechanism. Wound Repair Regen 2012;20:n/a-22.

48 Badr G. Camel whey protein enhances diabetic wound healing in a streptozotocin-induced diabetic mouse model: the critical role of B-Defensin-1, -2 and -3. Lipids Health Dis 2013;12:46.

49 Tie L, An Y, Han J, et al. Genistein accelerates refractory wound healing by suppressing superoxide and FoxO1/iNOS pathway in type 1 diabetes. J Nutr Biochem 2013;24:88-96.

50 Dhall S, Do DC, Garcia M, et al. Generating and reversing chronic wounds in diabetic mice by manipulating wound redox parameters. J Diabetes Res 2014;2014:562625

51 Fadini GP, Albiero M, Millioni R, et al. The molecular signature of impaired diabetic wound healing identifies serpinB3 as a healing biomarker. Diabetologia 2014;57:1947-56.

52 Gooyit M, Peng Z, Wolter WR, et al. A chemical biological strategy to facilitate diabetic wound healing. ACS Chem Biol 2014;9:105-10.

53 Liu F, Chen D-D, Sun X, et al. Hydrogen sulfide improves wound healing via restoration of endothelial progenitor cell functions and activation of angiopoietin-1 in type 2 diabetes. Diabetes 2014;63:1763-78.

54 Moura LIF, Dias AMA, Leal EC, et al. Chitosan-based dressings loaded with neurotensin--an efficient strategy to improve early diabetic wound healing. Acta Biomater 2014;10:843-57.

55 Moura LIF, Dias AMA, Suesca E, et al. Neurotensin-loaded collagen dressings reduce inflammation and improve wound healing in diabetic mice. Biochim Biophys Acta 2014;1842:32-43.

56 Steinstraesser L, Lam MC, Jacobsen F, et al. Skin electroporation of a plasmid encoding hCAP-18/LL-37 host defense peptide promotes wound healing. Mol Ther 2014;22:734-42.

57 Wang X-Q, Lee S, Wilson H, et al. Ganglioside GM3 depletion reverses impaired wound healing in diabetic mice by activating IGF-1 and insulin receptors. J Invest Dermatol 2014;134:1446-55. 
58 Avitabile S, Odorisio T, Madonna S, et al. Interleukin-22 promotes wound repair in diabetes by improving keratinocyte pro-healing functions. J Invest Dermatol 2015;135:2862-70.

59 Hozzein WN, Badr G, Al Ghamdi AA, et al. Topical application of propolis enhances cutaneous wound healing by promoting TGF-beta/Smad-mediated collagen production in a streptozotocininduced type I diabetic mouse model. Cell Physiol Biochem 2015;37:940-54.

60 Leal EC, Carvalho E, Tellechea A, et al. Substance P promotes wound healing in diabetes by modulating inflammation and macrophage phenotype. Am J Pathol 2015;185:1638-48.

$61 \mathrm{Lim}$ Y-C, Bhatt MP, Kwon M-H, et al. Proinsulin C-peptide prevents impaired wound healing by activating angiogenesis in diabetes. $J$ Invest Dermatol 2015;135:269-78.

62 Rebalka IA, Raleigh MJ, D'Souza DM, et al. Inhibition of PAl-1 via PAl-039 improves dermal wound closure in diabetes. Diabetes 2015;64:2593-602.

63 Wong SL, Demers M, Martinod K, et al. Diabetes primes neutrophils to undergo NETosis, which impairs wound healing. Nat Med 2015;21:815-9.

64 Badr G, Hozzein WN, Badr BM, et al. Bee Venom Accelerates Wound Healing in Diabetic Mice by Suppressing Activating Transcription Factor-3 (ATF-3) and Inducible Nitric Oxide Synthase (iNOS)-Mediated Oxidative Stress and Recruiting Bone Marrow-Derived Endothelial Progenitor Cells. J Cell Physiol 2016;231:2159-71.

65 Desposito D, Chollet C, Taveau C, et al. Improvement of skin wound healing in diabetic mice by kinin B2 receptor blockade. Clin Sci 2016;130:45-56.

66 Dong M-W, Li M, Chen J, et al. Activation of $\alpha 7 n A C h R$ promotes diabetic wound healing by suppressing age-induced TNF- $\alpha$ production. Inflammation 2016;39:687-99.

67 Eo H, Lee H-J, Lim Y. Ameliorative effect of dietary genistein on diabetes induced hyper-inflammation and oxidative stress during early stage of wound healing in alloxan induced diabetic mice. Biochem Biophys Res Commun 2016;478:1021-7.

68 Katagiri S, Park K, Maeda Y, et al. Overexpressing IRS1 in endothelial cells enhances angioblast differentiation and wound healing in diabetes and insulin resistance. Diabetes 2016;65:2760-71.

69 Long M, Rojo de la Vega M, Wen Q, et al. An essential role of Nrf2 in diabetic wound healing. Diabetes 2016;65:780-93.

70 Soares MA, Cohen OD, Low YC, et al. Restoration of Nrf2 signaling normalizes the regenerative niche. Diabetes 2016;65:633-46.

71 Tan JTM, Prosser HCG, Dunn LL, et al. High-Density lipoproteins rescue diabetes-impaired angiogenesis via scavenger receptor class B type I. Diabetes 2016;65:3091-103.

72 Tellechea A, Leal EC, Kafanas A, et al. Mast cells regulate wound healing in diabetes. Diabetes 2016;65:2006-19.

73 Wu Y, Quan Y, Liu Y, et al. Hyperglycaemia inhibits REG3A expression to exacerbate TLR3-mediated skin inflammation in diabetes. Nat Commun 2016;7:13393.

74 Yu J-W, Deng Y-P, Han X, et al. Metformin improves the angiogenic functions of endothelial progenitor cells via activating AMPK/eNOS pathway in diabetic mice. Cardiovasc Diabetol 2016;15:88.

75 Agostinho Hunt AM, Gibson JA, Larrivee CL, et al. A bioluminescent Pseudomonas aeruginosa wound model reveals increased mortality of type 1 diabetic mice to biofilm infection. $J$ Wound Care 2017;26:S24-33.

76 Nishikai-Yan Shen T, Kanazawa S, Kado M, et al. Interleukin-6 stimulates Akt and p38 MAPK phosphorylation and fibroblast migration in non-diabetic but not diabetic mice. PLoS One 2017;12:e0178232.

77 Shin J, Yang SJ, Lim Y. Gamma-Tocopherol supplementation ameliorated hyper-inflammatory response during the early cutaneous wound healing in alloxan-induced diabetic mice. Exp Biol Med 2017;242:505-15.

78 Singla R, Soni S, Patial V, et al. In vivo diabetic wound healing potential of nanobiocomposites containing bamboo cellulose nanocrystals impregnated with silver nanoparticles. Int J Biol Macromol 2017;105:45-55.

79 Wang Y, Bai Y, Li Y, et al. II-15 enhances activation and IGF-1 production of dendritic epidermal T cells to promote wound healing in diabetic mice. Front Immunol 2017:8:1557.

80 Xu C, Bentinger M, Savu O, et al. Mono-epoxy-tocotrienol- $\alpha$ enhances wound healing in diabetic mice and stimulates in vitro angiogenesis and cell migration. $J$ Diabetes Complications 2017;31:4-12.
81 Zhao H, Chen J, Chai J, et al. Cytochrome P450 (CYP) epoxygenases as potential targets in the management of impaired diabetic wound healing. Lab Invest 2017;97:782-91.

82 Zhao H, Lu S, Chai J, et al. Hydrogen sulfide improves diabetic wound healing in ob/ob mice via attenuating inflammation. $J$ Diabetes Complications 2017;31:1363-9.

83 Botusan IR, Zheng X, Narayanan S, et al. Deficiency of liver-derived insulin-like growth factor-I (IGF-I) does not interfere with the skin wound healing rate. PLoS One 2018;13:e0193084.

84 Cardoso SH, de Oliveira CR, Guimarães AS, et al. Synthesis of newly functionalized 1,4-naphthoquinone derivatives and their effects on wound healing in alloxan-induced diabetic mice. Chem Biol Interact 2018;291:55-64.

85 Hozzein WN, Badr G, Badr BM, et al. Bee venom improves diabetic wound healing by protecting functional macrophages from apoptosis and enhancing Nrf2, Ang-1 and Tie-2 signaling. Mol Immunol 2018;103:322-35.

86 Jiménez-Jiménez $C$, Lara-Chica $M$, Palomares $B$, et al. Effect of $\mathrm{N}$-acyl-dopamines on beta cell differentiation and wound healing in diabetic mice. Biochim Biophys Acta Mol Cell Res 2018;1865:1539-51.

87 Shi Y, Fan S, Wang D, et al. Foxo1 inhibition potentiates endothelial angiogenic functions in diabetes via suppression of ROCK1/Drp1 mediated mitochondrial fission. Biochim Biophys Acta Mol Basis Dis 2018;1864:2481-94.

88 Wang F, Liu B, Yu Z, et al. Effects of CD100 promote wound healing in diabetic mice. J Mol Histol 2018;49:277-87.

89 Yan J, Tie G, Wang S, et al. Diabetes impairs wound healing by Dnmt1-dependent dysregulation of hematopoietic stem cells differentiation towards macrophages. Nat Commun 2018;9:33

90 Yu B, Alboslemy T, Safadi F, et al. Glycoprotein nonmelanoma clone $B$ regulates the crosstalk between macrophages and mesenchymal stem cells toward wound repair. J Invest Dermatol 2018;138:219-27.

91 Yuan Y, Das SK, Li M. Vitamin D ameliorates impaired wound healing in streptozotocin-induced diabetic mice by suppressing NF-кB-mediated inflammatory genes. Biosci Rep 2018;38. doi:10.1042/BSR20171294. [Epub ahead of print: 27 Apr 2018].

$92 \mathrm{Li} \mathrm{X}, \mathrm{Wu}$ G, Han F, et al. Sirt1 activation promotes angiogenesis in diabetic wounds by protecting endothelial cells against oxidative stress. Arch Biochem Biophys 2019;661:117-24.

93 Yang $\mathrm{C}-\mathrm{T}$, Chen L, Chen W-L, et al. Hydrogen sulfide primes diabetic wound to close through inhibition of NETosis. Mol Cell Endocrinol 2019;480:74-82.

94 Galiano RD, Michaels J, Dobryansky M, et al. Quantitative and reproducible murine model of excisional wound healing. Wound Repair Regen 2004;12:485-92.

95 Davidson JM, Yu F, Opalenik SR. Splinting strategies to overcome confounding wound contraction in experimental animal models. Adv Wound Care 2013;2:142-8.

96 American Diabetes Association. Diagnosis and classification of diabetes mellitus. Diabetes Care 2009;32 Suppl 1:S62-7.

97 Lenzen S. The mechanisms of alloxan- and streptozotocin-induced diabetes. Diabetologia 2008;51:216-26.

98 Breyer MD, Böttinger E, Brosius FC, et al. Mouse models of diabetic nephropathy. J Am Soc Nephrol 2005;16:27-45.

99 Furman BL. Streptozotocin-Induced diabetic models in mice and rats. Curr Protoc Pharmacol 2015;70:1-20.

100 Gurley SB, Clare SE, Snow KP, et al. Impact of genetic background on nephropathy in diabetic mice. Am J Physiol Renal Physiol 2006;290:F214-22.

101 Allen TJ, Cooper ME, Lan HY. Use of genetic mouse models in the study of diabetic nephropathy. Curr Atheroscler Rep 2004;6:197-202.

102 Coleman DL. Obese and diabetes: two mutant genes causing diabetes-obesity syndromes in mice. Diabetologia 1978;14:141-8.

103 Lee YT, Lin HY, Chan YWF, et al. Mouse models of atherosclerosis: a historical perspective and recent advances. Lipids Health Dis 2017;16:12

104 O'Brien PD, Sakowski SA, Feldman EL. Mouse models of diabetic neuropathy. Ilar J 2014;54:259-72.

105 Krishna SM, Omer SM, Golledge J. Evaluation of the clinical relevance and limitations of current pre-clinical models of peripheral artery disease. Clin Sci 2016;130:127-50.

106 Sullivan KA, Hayes JM, Wiggin TD, et al. Mouse models of diabetic neuropathy. Neurobiol Dis 2007;28:276-85.

107 Wu KK, Huan Y. Diabetic atherosclerosis mouse models. Atherosclerosis 2007;191:241-9. 